\title{
Development of Nitrolactonization Mediated by Iron(III) Nitrate Nonahydrate
}

\author{
Tomoyuki Yoshimura, ${ }^{*}$ Yuki Umeda, Risako Takahashi, and Jun-ichi Matsuo \\ Division of Pharmaceutical Sciences, Graduate School of Medical Sciences, Kanazawa University; Kakuma-machi, \\ Kanazawa, Ishikawa 920-1192, Japan.
}

Received August 13, 2020; accepted September 14, 2020

\begin{abstract}
The nitrolactonization of alkenyl carboxylic acids mediated by $\mathrm{Fe}\left(\mathrm{NO}_{3}\right)_{3} \cdot 9 \mathrm{H}_{2} \mathrm{O}$ has been developed. Nitrolactones were obtained in up to $93 \%$ yield by treatment of alkenyl carboxylic acids with $\mathrm{Fe}\left(\mathrm{NO}_{3}\right)_{3} \cdot 9 \mathrm{H}_{2} \mathrm{O}$. Mechanistic studies disclosed that the reaction proceeded through a radical intermediate generated from addition of $\mathrm{NO}_{2}$ to alkenyl carboxylic acids.
\end{abstract}

Key words nitrolactonization; iron(III) nitrate nonahydrate; nitrogen dioxide; radical intermediate

\section{Introduction}

Nitro compounds are useful synthons in synthetic organic chemistry due to their availability for various transformations. The strong electron-withdrawing property of the nitro group plays an important role in $\mathrm{C}-\mathrm{C}$ bond formation reactions ${ }^{1,2}$ including the nitro-aldol reaction (Henry reaction), ${ }^{3-5)} \mathrm{Mi}$ chael reaction, ${ }^{6-11)}$ and alkylation. ${ }^{12,13)}$ Nitrones and nitrile oxides generated from nitro compounds undergo 1,3-dipole cycloaddition reaction to give various heterocycles. ${ }^{14-16)}$ The nitro group can be converted into a carbonyl or amino group through the Nef reaction ${ }^{17,18)}$ or reduction, respectively. ${ }^{19)}$ For these reasons, nitro compounds are heavily used as versatile starting materials in the synthesis of natural products and drugs. ${ }^{20-25)}$ Nitration mediated by iron(III) nitrate nonahydrate $\left(\mathrm{Fe}\left(\mathrm{NO}_{3}\right)_{3} \cdot 9 \mathrm{H}_{2} \mathrm{O}\right)$ has been recently reported. ${ }^{26-35)}$ The use of $\mathrm{Fe}\left(\mathrm{NO}_{3}\right)_{3} \cdot 9 \mathrm{H}_{2} \mathrm{O}$ has attracted attention as a source of nitrogen dioxide in organic synthesis due to its properties as a readily available reagent of low toxicity and cost. It has been suggested that these nitrations proceed via a radical intermediate derived by addition of nitrogen dioxide generated from $\mathrm{Fe}\left(\mathrm{NO}_{3}\right)_{3} \cdot 9 \mathrm{H}_{2} \mathrm{O}$ with heating. ${ }^{36)}$ We envisioned the novel development of a nitrolactonization of styrene derivative $\mathbf{1}$ mediated by $\mathrm{Fe}\left(\mathrm{NO}_{3}\right)_{3} \cdot 9 \mathrm{H}_{2} \mathrm{O}$ (Chart 1). Because nitrolactone 2 could lead to 1,2-aminoalcohol and amino acid derivatives bearing a tetrasubstituted carbon center, the development of a new nitrolactonization reaction leading to substituted nitrolactones would be useful not only in natural product synthesis but in medicinal chemistry.

Precursor 3a for nitrolactonization was prepared from benzene by Friedel-Crafts acylation with succinic anhydride followed by a Wittig reaction of the resultant ketone 4a (Chart 2).

Nitrolactonization of carboxylic acid 3a was investigated according to the reported method of generating $\mathrm{NO}_{2}$ from $\mathrm{Fe}\left(\mathrm{NO}_{3}\right)_{3} \cdot 9 \mathrm{H}_{2} \mathrm{O}^{37)}$ (Table 1). Treatment of 3a with 0.5 equivalent (equiv.) of $\mathrm{Fe}\left(\mathrm{NO}_{3}\right)_{3} \cdot 9 \mathrm{H}_{2} \mathrm{O}$ in 1,2-dichlorobenzene at $130^{\circ} \mathrm{C}$ for $4 \mathrm{~h}$ afforded nitrolactone $\mathbf{5 a}$, hydroxylactone $\mathbf{6 a}$, and lactone $7 \mathbf{a}$ in 48,3 , and $7 \%$ yields, respectively (entry 1). The nitration regioselectively took place at the olefinic moiety of $\mathbf{3 a}$ to produce $\mathbf{5 a}$, with the product structure confirmed by $\mathrm{X}$-ray crystallographic analysis. ${ }^{38)}$ Hydroxylactone 6a was en- visioned to be produced via a nitrite lactone intermediate due to the ambident property of $\mathrm{NO}_{2}$ while lactone 7a was likely produced via proto-lactonization mediated by $\mathrm{HNO}_{3}$ that was generated from $\mathrm{NO}_{2}$ gas and water. ${ }^{39)}$ The effect of the metal nitrate was investigated by use of copper(II) nitrate, zinc nitrate, and silver nitrate in the reaction (entries 2-4). These metal nitrates afforded nitrolactone $\mathbf{5}$ in lower yield when compared to the reaction with $\mathrm{Fe}\left(\mathrm{NO}_{3}\right)_{3}$ (entry 1 vs. entries $2-4)$. Reducing or increasing the number of equivalents of $\mathrm{Fe}\left(\mathrm{NO}_{3}\right)_{3}$ resulted in diminished yields (entry 1 vs. entries 5 and 6). The differences in the yields of products involved in the number of equivalent of $\mathrm{Fe}\left(\mathrm{NO}_{3}\right)_{3}$ would attribute the concentration of $\mathrm{NO}_{2}$ generated for $\mathrm{Fe}\left(\mathrm{NO}_{3}\right)_{3}$. Lower equivalent of $\mathrm{Fe}\left(\mathrm{NO}_{3}\right)_{3}$ would not be enough to undergo $\mathrm{NO}_{2}$ addition reaction but lead to decomposition of 5a probably due to the equilibrium mixture between $\mathrm{NO}_{2}$ and its various reactive isomers of $\mathrm{N}_{2} \mathrm{O}_{4}$ (entry 5). ${ }^{40-43)}$ Higher equivalent of $\mathrm{Fe}\left(\mathrm{NO}_{3}\right)_{3}$ would generate a high concentration of $\mathrm{HNO}_{3}$, which lead to proto-lactonization rather than radical addition of $\mathrm{NO}_{2}$ (entry $6)$. To investigate the assumption that the heating-up time and reaction temperature would affect the reaction progress and yield, the reaction mixture was quickly heated (entries 7-9). When the reaction was conducted in a pre-heated oil bath at $130^{\circ} \mathrm{C}$, nitrolactone $\mathbf{5 a}$ was produced in an improved yield of $58 \%$ and the reaction time was shortened (entry 1 vs. entry 7). Addition of $\mathrm{KHCO}_{3}$ as a base to suppress the formation of byproduct 7a did not result in an improved yield of 5a (entry 8 ). Addition of proton-sponge ${ }^{\circledR}$ resulted in a complex product

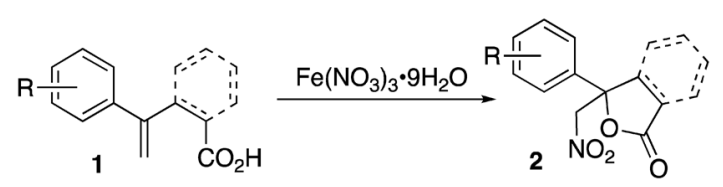

Chart 1. Nitrolactonization Mediated by $\mathrm{Fe}\left(\mathrm{NO}_{3}\right)_{3} \cdot 9 \mathrm{H}_{2} \mathrm{O}$

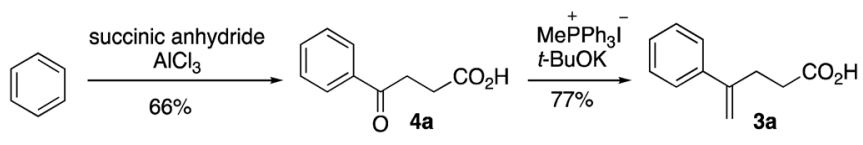

Chart 2. Synthesis of Precursor 3a 
Table 1. Optimization of Reaction Conditions ${ }^{a}$

\begin{tabular}{|c|c|c|c|c|c|c|}
\hline \multirow{3}{*}{ Entry } & $3 a \frac{m}{1,2-d i c}$ & & \multicolumn{2}{|c|}{$\mathrm{O}{ }_{6}$} & & \\
\hline & \multirow{2}{*}{ Metal nitrate } & \multirow{2}{*}{$\mathrm{X}$} & \multirow{2}{*}{ Time (h) } & \multicolumn{3}{|c|}{ Yield (\%) } \\
\hline & & & & $5 \mathrm{a}$ & $6 a$ & $7 \mathbf{a}$ \\
\hline 1 & $\mathrm{Fe}\left(\mathrm{NO}_{3}\right)_{3} \cdot 9 \mathrm{H}_{2} \mathrm{O}$ & 0.5 & 4 & 48 & 3 & 7 \\
\hline 2 & $\mathrm{Cu}\left(\mathrm{NO}_{3}\right)_{2} \cdot 3 \mathrm{H}_{2} \mathrm{O}$ & 0.75 & 5 & 36 & 12 & 4 \\
\hline 3 & $\mathrm{Zn}\left(\mathrm{NO}_{3}\right)_{2} \cdot 6 \mathrm{H}_{2} \mathrm{O}$ & 0.75 & 3 & 8 & 8 & 30 \\
\hline 4 & $\mathrm{AgNO}_{3}$ & 1.5 & 3 & 3 & 4 & 0 \\
\hline 5 & $\mathrm{Fe}\left(\mathrm{NO}_{3}\right)_{3} \cdot 9 \mathrm{H}_{2} \mathrm{O}$ & 0.34 & 4 & 7 & 4 & 5 \\
\hline 6 & $\mathrm{Fe}\left(\mathrm{NO}_{3}\right)_{3} \cdot 9 \mathrm{H}_{2} \mathrm{O}$ & 0.67 & 4.5 & 24 & 3 & 49 \\
\hline $7^{b)}$ & $\mathrm{Fe}\left(\mathrm{NO}_{3}\right)_{3} \cdot 9 \mathrm{H}_{2} \mathrm{O}$ & 0.5 & 1.5 & 58 & 5 & 13 \\
\hline $8^{b, c)}$ & $\mathrm{Fe}\left(\mathrm{NO}_{3}\right)_{3} \cdot 9 \mathrm{H}_{2} \mathrm{O}$ & 0.5 & 2.5 & 54 & approx. $10^{d)}$ & 7 \\
\hline $9^{b, e)}$ & $\mathrm{Fe}\left(\mathrm{NO}_{3}\right)_{3} \cdot 9 \mathrm{H}_{2} \mathrm{O}$ & 0.5 & 24 & 0 & 0 & 0 \\
\hline
\end{tabular}

a) A stirring mixture of metal nitrate and 3 in 1,2-dichlorobenzen was heated gradually from room temperature (r.t.) to $130{ }^{\circ} \mathrm{C}$ and after temperature reached at $130{ }^{\circ} \mathrm{C}$, the reaction was run for the indicated time. $b$ ) The reaction was performed in pre-heated oil bath $\left.\left(130^{\circ} \mathrm{C}\right) . c\right) 0.3$ equiv. of $\mathrm{KHCO}_{3}$ was added. $\left.d\right) \mathrm{A}$ small amount of $4-$ phenyl4-oxobutanoic acid was contained. e) 1.0 equiv. of proton-sponge ${ }^{\circledR}$ was added.

Table 2. Effects of Substituent at Phenyl Group

\begin{tabular}{cccccccc} 
& & & \\
\hline \\
\hline \hline
\end{tabular}

Table 3. Nitrolactonization of Benzoic Acid Derivatives 8

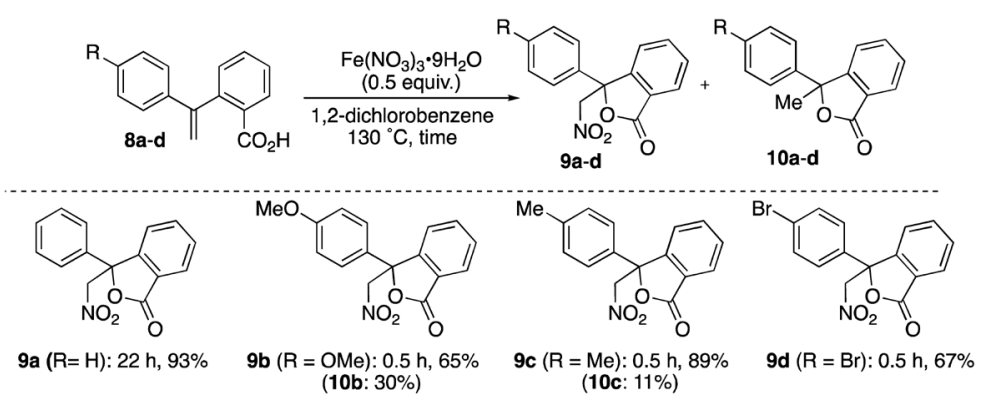

mixture (entry 9).

The effect of substitution at the phenyl group of starting material $\mathbf{3}$ was examined (Table 2). Treatment of $\mathbf{3 b}$ with $\mathrm{Fe}\left(\mathrm{NO}_{3}\right)_{3} \cdot 9 \mathrm{H}_{2} \mathrm{O}$ in 1,2-dichlorobenzene at $130{ }^{\circ} \mathrm{C}$ afforded nitrolactone $\mathbf{5 b}$ and lactone $\mathbf{7 b}$ in 12 and $69 \%$ yields, respectively, without production of hydroxylactone. The yield of $\mathbf{7 b}$ was higher than that of $\mathbf{5 b}$ because the electron-donating effect of the methoxy group prompted a protonation reaction instead of the radical addition of nitrogen dioxide (entry 1). Substituents bearing electron-withdrawing groups such as $\mathrm{NO}_{2}$ and $\mathrm{CN}$ at phenyl group resulted in low yields of $\mathbf{5 c}$ and $\mathbf{5 d}$ due to com-

plication in reaction (entries 2 and 3).

The nitrolactonization of benzoic acid derivatives $\mathbf{8 a}-\mathbf{d}$ was investigated to determine whether yields would improve due to acceleration of the cyclization rate and stabilization of the radical intermediate (vide infra) (Table 3). The reaction of $8 \mathbf{a}$ for $22 \mathrm{~h}$ proceeded smoothly to give $\mathbf{9} \mathbf{a}^{44)}$ as a sole product in $93 \%$ yield. Nitrolactonization of compounds $\mathbf{8 b}$ and $8 \mathbf{c}$ bearing electron-donating substituents at the aromatic ring produced not only $9 \mathbf{b}$ (65\% yield) and 9c (89\% yield), respectively, but also $\mathbf{1 0 b}$ ( $30 \%$ yield) and $\mathbf{1 0 c}(11 \%$ yield), respectively, as a result of addition of nitrogen dioxide and the 


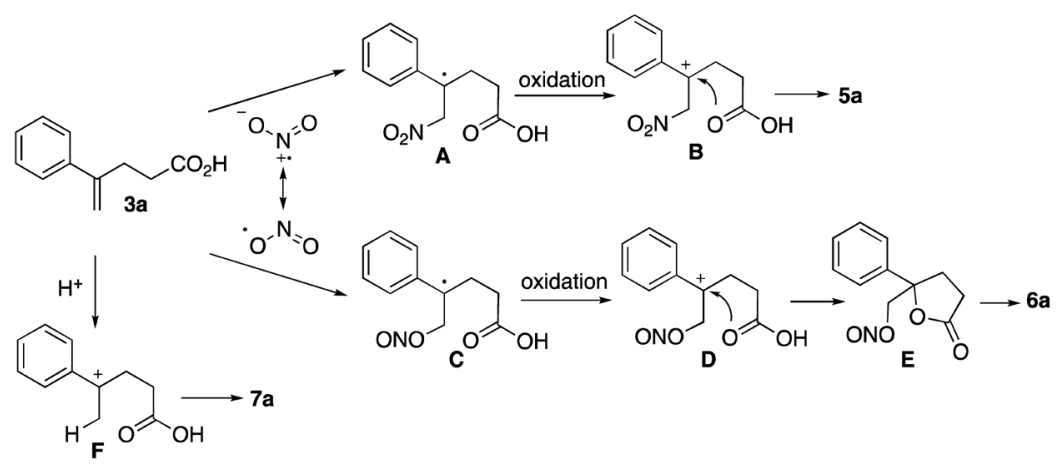

Chart 3. Plausible Mechanism

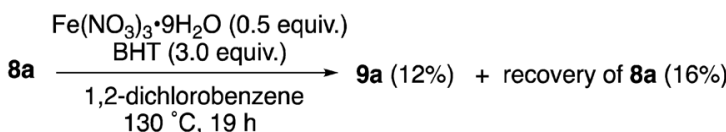

Chart 4. Effect of BHT for Nitrolactonization

competing formation of a stable cation at the double benzylic position. Substitution of a bromo group at the aromatic ring, which can be converted into various functional groups, resulted in a reduced yield of nitrolactone 9d (67\%) but lactone 10d was not observed.

A plausible mechanism is shown in Chart 3. Nitrogen dioxide generated from $\mathrm{Fe}\left(\mathrm{NO}_{3}\right)_{3} \cdot 9 \mathrm{H}_{2} \mathrm{O}$ by pyrolysis would react with $\mathbf{3} \mathbf{a}$ at nitrogen atom to lead to radical intermediate $\mathbf{A}$. Oxidation of $\mathbf{A}$, which might be mediated by $\mathrm{Fe}\left(\mathrm{NO}_{3}\right)_{3}$ and/or $\mathrm{HNO}_{3}$, would give carbocation $\mathbf{B}$, which would undergo cyclization to form 5a. This radical mechanism is supported by the fact that nitrolactonization of $\mathbf{8 a}$ in the presence of 2,6-di-tert-butyl-4-methylphenol (BHT) as a radical scavenger reduced the yield of $9 \mathbf{a}(12 \%)$ (Table 3, entry 1 vs. Chart 4) and recovered $\mathbf{8 a}$ in $16 \%$ yield. Isolation of $\mathbf{8 a}$ and $9 \mathbf{a}$ was possible although other products could be unidentified because of complication in the reaction. Through a similar process leading to production of 5a, hydroxylactone $\mathbf{6 a}$ would be obtained through nitrite radical intermediates $\mathbf{C}$, carbocation $\mathbf{D}$, and nitrite $\mathbf{E}$, sequentially. It was assumed that cleavage of the $\mathrm{O}-\mathrm{NO}$ bond of $\mathbf{E}$ took place in the reaction media or by addition of water during the workup stage. The ambident property of $\mathrm{NO}_{2}$ might produce nitrite intermediate $\mathbf{C}$. It had been reported not only that partial pressure of oxygen influenced the production of nitrite adducts in the reaction of isobutylene and $\mathrm{N}_{2} \mathrm{O}_{4}$ which has been regarded as an equilibrium mixture with $\mathrm{NO}_{2},{ }^{40-43,45)}$ but also that oxidative cleavage of a tetrasubstituted olefin catalyzed by $\mathrm{Fe}\left(\mathrm{NO}_{3}\right)_{3}$ would proceed via a dinitrite intermediate in the presence of molecular oxygen. ${ }^{37)}$ We speculated that production of $\mathbf{6 a}$ might be related to the amount of dissolved oxygen in the reaction media, however the detailed effect of the dissolved oxygen on the production of $\mathbf{6 a}$ was unclear. Lactone 7a was obtained via carbocation $\mathbf{F}$ by catalysis of nitric acid generated from $\mathrm{H}_{2} \mathrm{O}$ and $\mathrm{NO}_{2}$ in the reaction media.

The nitrolactonization of carboxylic acids mediated by $\mathrm{Fe}\left(\mathrm{NO}_{3}\right)_{3} \cdot 9 \mathrm{H}_{2} \mathrm{O}$ was developed. Mechanistic studies disclosed that the reaction proceeded via a radical intermediate derived from addition of $\mathrm{NO}_{2}$, which was generated by pyrolysis of $\mathrm{Fe}\left(\mathrm{NO}_{3}\right)_{3} \cdot 9 \mathrm{H}_{2} \mathrm{O}$, at the olefin moiety. These results demon- strate the utility of $\mathrm{Fe}\left(\mathrm{NO}_{3}\right)_{3} \cdot 9 \mathrm{H}_{2} \mathrm{O}$ as a source of nitrogen dioxide and could lead to the development of new reactions mediated by $\mathrm{Fe}\left(\mathrm{NO}_{3}\right)_{3} \cdot 9 \mathrm{H}_{2} \mathrm{O}$.

\section{Experimental}

General ${ }^{1} \mathrm{H}-\mathrm{NMR}$ were measured in $\mathrm{CDCl}_{3}$ or dimethyl sulfoxide (DMSO)- $d_{6}$ solution and referenced from tetramethylsilane (TMS) $(0.00 \mathrm{ppm})$ using JEOL JNM ECA-600 $(600 \mathrm{MHz})$ or JEOL JNM ECA-400 (400 MHz) spectrophotometer, unless otherwise noted. ${ }^{13} \mathrm{C}-\mathrm{NMR}$ were measured in $\mathrm{CDCl}_{3}$ solution and referenced to $\mathrm{CDCl}_{3}(77.0 \mathrm{ppm})$, DMSO$d_{6}\left(\left(\mathrm{CD}_{3}\right)_{3} \mathrm{SO}\right)(39.5 \mathrm{ppm})$ or $\mathrm{CD}_{3} \mathrm{OD}(49.0 \mathrm{ppm})$ using JEOL JNM ECA-600 (150 MHz) or JEOL JNM ECX-400 (100 MHz) spectrophotometer, unless otherwise noted. Chemical shifts are reported in ppm. When peak multiplicities are reported, the following abbreviations are used: s, singlet; $d$, doublet; $t$, triplet, q, quartet; m, multiplet; br, broadened. IR spectra were recorded on Horiba IR-710 spectrometer. Mass spectra were obtained on JEOL JMS-T100TD. Flash column chromatography was performed on Silica Gel (SiliaFlash ${ }^{\circledR}$ F60). TLC was performed on precoated plates $(0.25 \mathrm{~mm}$, silica gel Merck Kieselgel $60 \mathrm{~F}_{245}$ ), and compounds were visualized with UV light and $p$-anisaldehyde stain or phosphomolybdic acid stain. Melting points were measured with Yanaco MICRO MELTING POINTAPPARATUS. 1,2-Dichlorobenzene was purchased from TOKYO CHMICAL INDUSTRY CO., LTD. (Japan) and used without any purifications. $\mathrm{Fe}\left(\mathrm{NO}_{3}\right)_{3} \cdot 9 \mathrm{H}_{2} \mathrm{O}$ was purchased from FUJIFILM Wako Pure Chemical Corporation (Japan) and used without any purifications.

Compounds $\mathbf{3 a}, \mathbf{b}^{46)} \mathbf{3} \mathbf{c},{ }^{47)} \mathbf{3 d},{ }^{48)}$ and, $\mathbf{8 a}-\mathbf{d}^{49)}$ were prepared according to the literatures and identified with ${ }^{1} \mathrm{H}-\mathrm{NMR}$ by comparison with the reported ones.

General Procedure 1: Optimization of Reaction Conditions (Table 1) A mixture of 3a $(47.0 \mathrm{mg}, 0.27 \mathrm{mmol})$ and metal nitrate in 1,2-dichlorobenzene $(2.7 \mathrm{~mL})$ was stirred at $130^{\circ} \mathrm{C}$. After being stirred for the indicated time in Table 1, the reaction was quenched by addition of sat. aq. $\mathrm{NaHCO}_{3}$ and the resulting mixture was filtered through a pad of Celite. The filtrate was extracted with $\mathrm{CH}_{2} \mathrm{Cl}_{2}$. The extracts were washed with brine, and dried over $\mathrm{Na}_{2} \mathrm{SO}_{4}$, filtered, and concentrated. The residue was purified through silica gel column chromatography (hexane/AcOEt $=8 / 2$ to $7 / 3$ ) to give $\mathbf{5 a}, \mathbf{6 a}$, and $\mathbf{7 a}$, respectively.

Entry 1

According to the general procedure 1, the reaction was performed with $\mathrm{Fe}\left(\mathrm{NO}_{3}\right)_{3} \cdot 9 \mathrm{H}_{2} \mathrm{O}(54.0 \mathrm{mg}, 0.13 \mathrm{mmol})$ for $4 \mathrm{~h}$ to give 5a (28.6 mg, 48\%), 6a (1.7 mg, 3\%), and $7 \mathbf{a}(3.5 \mathrm{mg}, 7 \%)$, 
respectively.

Entry 2

According to the general procedure 1, the reaction was performed with $\mathrm{Cu}\left(\mathrm{NO}_{3}\right)_{2} \cdot 3 \mathrm{H}_{2} \mathrm{O}(48.3 \mathrm{mg}, 0.2 \mathrm{mmol})$ for $5 \mathrm{~h}$ to give 5a $(21.0 \mathrm{mg}, 36 \%)$, 6a $(6.4 \mathrm{mg}, 12 \%)$, and $7 \mathbf{a}(1.7 \mathrm{mg}, 4 \%)$, respectively.

Entry 3

According to the general procedure 1, the reaction was performed with $\mathrm{Zn}\left(\mathrm{NO}_{3}\right)_{2} \cdot 6 \mathrm{H}_{2} \mathrm{O}(59.5 \mathrm{mg}, 0.2 \mathrm{mmol})$ for $3 \mathrm{~h}$ to give 5a (4.6 mg, 8\%), 6a (3.9 mg, 8\%), and 7a (14.2 mg, 30\%), respectively.

\section{Entry 4}

According to the general procedure 1, the reaction was performed with $\mathrm{AgNO}_{3}(68.0 \mathrm{mg}, 0.4 \mathrm{mmol})$ for $3 \mathrm{~h}$ to give 5a (1.6 mg, 3\%), 6a (1.9 mg, 4\%), and recovered 3a (1.2 mg, 3\%), respectively.

\section{Entry 5}

According to the general procedure 1, the reaction was performed with $\mathrm{Fe}\left(\mathrm{NO}_{3}\right)_{3} \cdot 9 \mathrm{H}_{2} \mathrm{O}(36.7 \mathrm{mg}, 0.09 \mathrm{mmol})$ for $4 \mathrm{~h}$ to give 5a $(4.3 \mathrm{mg}, 7 \%)$, 6a $(2.1 \mathrm{mg}, 4 \%)$, and $7 \mathbf{a}(2.3 \mathrm{mg}, 5 \%)$, respectively.

Entry 6

According to the general procedure 1, the reaction was performed with $\mathrm{Fe}\left(\mathrm{NO}_{3}\right)_{3} \cdot 9 \mathrm{H}_{2} \mathrm{O}(72.0 \mathrm{mg}, 0.18 \mathrm{mmol})$ for $4.5 \mathrm{~h}$ to give $\mathbf{5 a}(14.4 \mathrm{mg}, 24 \%), \mathbf{6 a}(1.5 \mathrm{mg}, 3 \%)$, and $7 \mathbf{a}(23.2 \mathrm{mg}$, $49 \%$ ), respectively.

\section{Entry 7}

A mixture of 3a $(44.0 \mathrm{mg}, 0.25 \mathrm{mmol})$ and $\mathrm{Fe}\left(\mathrm{NO}_{3}\right)_{3} \cdot 9 \mathrm{H}_{2} \mathrm{O}$ $(50.5 \mathrm{mg}, 0.13 \mathrm{mmol})$ in 1,2 -dichlorobenzene $(2.5 \mathrm{~mL})$ was lowered into pre-heated oil bath $\left(130^{\circ} \mathrm{C}\right)$. After being stirred for $1.5 \mathrm{~h}$ at same temperature, the mixture was cooled to r.t. and quenched by addition of sat. aq. $\mathrm{NaHCO}_{3}$. The resulting mixture was filtered through a pad of Celite. The filtrate was extracted with $\mathrm{CH}_{2} \mathrm{Cl}_{2}$. The extracts were washed with brine, dried over $\mathrm{Na}_{2} \mathrm{SO}_{4}$, filtered, and concentrated. The residue was purified through silica gel column chromatography (hexane/ $\mathrm{AcOEt}=9 / 1$ to $3 / 2)$ to give $\mathbf{5 a}(31.8 \mathrm{mg}, 58 \%)$, 6a $(2.6 \mathrm{mg}$, $5 \%$ ), and 7 a $(5.6 \mathrm{mg}, 13 \%)$, respectively.

\section{Entry 8}

A mixture of 3a $(44.0 \mathrm{mg}, 0.25 \mathrm{mmol}), \mathrm{Fe}\left(\mathrm{NO}_{3}\right)_{3} \cdot 9 \mathrm{H}_{2} \mathrm{O}$ $(50.5 \mathrm{mg}, 0.13 \mathrm{mmol})$, and $\mathrm{KHCO}_{3}(7.5 \mathrm{mg}, 0.075 \mathrm{mmol})$ in 1,2-dichlorobenzene $(2.5 \mathrm{~mL})$ was lowered into pre-heated oil bath $\left(130^{\circ} \mathrm{C}\right)$. After being stirred for $2.5 \mathrm{~h}$ at same temperature, the mixture was cooled to r.t. and quenched by addition of sat. aq. $\mathrm{NaHCO}_{3}$. The resulting mixture was filtered through a pad of Celite. The filtrate was extracted with $\mathrm{CH}_{2} \mathrm{Cl}_{2}$. The extracts were washed with brine, dried over $\mathrm{Na}_{2} \mathrm{SO}_{4}$, filtered, and concentrated. The residue was purified through silica gel column chromatography (hexane/AcOEt $=9 / 1$ to $3 / 2$ ) to give 5a $(29.6 \mathrm{mg}, 54 \%)$, 6a $(4.8 \mathrm{mg}$, a small amount of 4-phenyl4-oxobutanoic acid was contaminated, approx. 10\%), and 7a (3.2 $\mathrm{mg}, 7 \%)$, respectively.

5-Nitromethyl-5-phenyloxolan-2-one (5a)

White solid; mp: $95.0-95.5^{\circ} \mathrm{C}$; IR $\left(\mathrm{CHCl}_{3}\right) \mathrm{cm}^{-1}$ : 1790 , 1560; ${ }^{1} \mathrm{H}-\mathrm{NMR}\left(\mathrm{CDCl}_{3}, 400 \mathrm{MHz}\right) \delta: 7.47-7.38(5 \mathrm{H}, \mathrm{m}), 4.81$ $(1 \mathrm{H}, \mathrm{d}, J=12.6 \mathrm{~Hz}), 4.75(1 \mathrm{H}, \mathrm{d}, J=12.6 \mathrm{~Hz}), 3.00-2.91(1 \mathrm{H}$, m), 2.75-2.66 (2H, m), 2.58-2.49 (1H, m); ${ }^{13} \mathrm{C}-\mathrm{NMR}\left(\mathrm{CDCl}_{3}\right.$, $150 \mathrm{MHz}) \delta$ : 174.7, 138.7, 129.1, 124.6, 84.6, 81.9, 31.8, 27.8; ${ }^{13} \mathrm{C}-\mathrm{NMR}\left(\mathrm{CD}_{3} \mathrm{OD}, 150 \mathrm{MHz}\right) \delta: 177.5,141.0,129.9,129.7$, 125.9, 86.6, 82.9, 33.6, 28.5; high resolution (HR)MS (DART) $m / z$ Calcd for $\mathrm{C}_{11} \mathrm{H}_{12} \mathrm{NO}_{4}\left[(\mathrm{M}+\mathrm{H})^{+}\right]$: 222.07663. Found
222.07629.

5-Hydroxymethyl-5-phenyloxolan-2-one $(\mathbf{6 a})^{50)}$

White solid; mp: $108.5-109.5^{\circ} \mathrm{C}$; IR $\left(\mathrm{CHCl}_{3}\right) \mathrm{cm}^{-1}$ : 3953, 1716, 1686; ${ }^{1} \mathrm{H}-\mathrm{NMR}\left(\mathrm{CDCl}_{3}, 400 \mathrm{MHz}\right) \delta: 7.40-7.34(5 \mathrm{H}, \mathrm{m})$, $3.88(1 \mathrm{H}, \mathrm{dd}, J=5.2,12.4 \mathrm{~Hz}), 3.73(1 \mathrm{H}, \mathrm{dd}, J=8.4,12.4 \mathrm{~Hz})$, 2.84-2.70 (2H, m), 2.57-2.49 (1H, m), 2.43-2.39 (1H, m), 1.91 $\left(1 \mathrm{H}, \mathrm{dd}, J=5.2,8.4 \mathrm{~Hz}\right.$ ); MS (DART) $m / z: 193\left[(\mathrm{M}+\mathrm{H})^{+}\right]$. The spectral data were identified with the reported ones.

5-Methyl-5-phenyloxolan-3-one $(7 \mathbf{a})^{51)}$

Yellow oil; IR $\left(\mathrm{CHCl}_{3}\right) \mathrm{cm}^{-1}: 1764,1683 ;{ }^{1} \mathrm{H}-\mathrm{NMR}\left(\mathrm{CDCl}_{3}\right.$, $400 \mathrm{MHz}) \delta: 7.38-7.29(5 \mathrm{H}, \mathrm{m}), 2.64-2.41(4 \mathrm{H}, \mathrm{m}), 1.73(3 \mathrm{H}$, s); MS (DART) $m / z: 177\left[(\mathrm{M}+\mathrm{H})^{+}\right]$. The spectral data were identified with the reported ones.

Nitrolactonization of $\mathbf{3 b}$ A mixture of $\mathbf{3 b}$ (51.6 $\mathrm{mg}$, $0.25 \mathrm{mmol})$ and $\mathrm{Fe}\left(\mathrm{NO}_{3}\right)_{3} \cdot 9 \mathrm{H}_{2} \mathrm{O}(50.5 \mathrm{mg}, 0.13 \mathrm{mmol})$ in 1,2 -dichlorobenzene $(2.5 \mathrm{~mL})$ was lowered into pre-heated oil bath $\left(130^{\circ} \mathrm{C}\right)$. After being stirred for $3 \mathrm{~h}$ at same temperature, the mixture was cooled to r.t. and the reaction was quenched by addition of sat. aq. $\mathrm{NaHCO}_{3}$. The resulting mixture was filtered through a pad of Celite. The filtrate was extracted with $\mathrm{CH}_{2} \mathrm{Cl}_{2}$. The extracts were washed with brine, and dried over $\mathrm{Na}_{2} \mathrm{SO}_{4}$, filtered, and concentrated. The residue was purified through silica gel column chromatography (hexane/ $\mathrm{AcOEt}=8 / 1$ to $6 / 4)$ to give $\mathbf{5 b}(7.8 \mathrm{mg}, 12 \%)$ and $\mathbf{7 b}(35.7 \mathrm{mg}$, $69 \%)$, respectively.

5-(4'-Methoxyphenyl)-5-nitromethyloxolan-2-one (5b)

Pale yellow solid; mp: $130.0-131.0^{\circ} \mathrm{C}$; IR $\left(\mathrm{CHCl}_{3}\right) \mathrm{cm}^{-1}$ : 1790, 1558; ${ }^{1} \mathrm{H}-\mathrm{NMR}\left(\mathrm{CDCl}_{3}, 400 \mathrm{MHz}\right) \delta: 7.33(2 \mathrm{H}, \mathrm{d}$, $J=9.0 \mathrm{~Hz}), 6.94(2 \mathrm{H}, \mathrm{d}, J=9.0 \mathrm{~Hz}), 4.78(1 \mathrm{H}, \mathrm{d}, J=12.4 \mathrm{~Hz})$, $4.71(1 \mathrm{H}, \mathrm{d}, J=12.4 \mathrm{~Hz}), 3.83(3 \mathrm{H}, \mathrm{s}), 2.92-2.87(1 \mathrm{H}, \mathrm{m})$, 2.73-2.64 (2H, m), 2.58-2.51 (1H, m); HRMS (DART) $m / z$ Calcd for $\mathrm{C}_{12} \mathrm{H}_{17} \mathrm{~N}_{2} \mathrm{O}_{5}\left[\left(\mathrm{M}+\mathrm{NH}_{4}\right)^{+}\right]$: 269.11375. Found 269.11193.

5-(4'-Methoxyphenyl)-5-methyloxolan-2-one (7b) ${ }^{52)}$

Pale yellow oil; IR $\left(\mathrm{CHCl}_{3}\right) \mathrm{cm}^{-1}$ : 1770, 1513, 1249; ${ }^{1} \mathrm{H}-\mathrm{NMR}\left(\mathrm{CDCl}_{3}, 400 \mathrm{MHz}\right) \delta: 7.30(2 \mathrm{H}, \mathrm{d}, J=8.8 \mathrm{~Hz}), 6.90$ $(2 \mathrm{H}, \mathrm{d}, J=8.8 \mathrm{~Hz}), 3.81(3 \mathrm{H}, \mathrm{s}), 2.63-2.37(4 \mathrm{H}, \mathrm{m}), 1.70(3 \mathrm{H}$, $\mathrm{s})$. The spectral data were identified with the reported ones.

Nitrolactonization of $3 \mathbf{c}$ A mixture of $3 \mathbf{c}(52.0 \mathrm{mg}$, $0.24 \mathrm{mmol})$ and $\mathrm{Fe}\left(\mathrm{NO}_{3}\right)_{3} \cdot 9 \mathrm{H}_{2} \mathrm{O}(48.5 \mathrm{mg}, 0.12 \mathrm{mmol})$ in 1,2-dichlorobenzene $(2.4 \mathrm{~mL})$ was lowered into pre-heated oil bath $\left(130^{\circ} \mathrm{C}\right)$. After being stirred for $2 \mathrm{~h}$ at same temperature, the mixture was cooled to r.t. and the reaction was quenched by addition of sat. aq. $\mathrm{NaHCO}_{3}$. The resulting mixture was filtered through a pad of Celite. The filtrate was extracted with $\mathrm{CH}_{2} \mathrm{Cl}_{2}$. The extracts were washed with brine, and dried over $\mathrm{Na}_{2} \mathrm{SO}_{4}$, filtered, and concentrated. The residue was purified through silica gel column chromatography (hexane/ $\mathrm{AcOEt}=5 / 1$ to $6 / 4)$ to give 5-(4'-nitrophenyl)-5-nitromethyloxolan-2-one (5c) (10.1 mg, 16\%) as pale yellow needles; mp: 141.0-142.0 ${ }^{\circ} \mathrm{C}$ (recrystallized from AcOEt/hexane); IR ( $\mathrm{KBr}$ ) $\mathrm{cm}^{-1}: 1795,1731,1606,1556,1378 ;{ }^{1} \mathrm{H}-\mathrm{NMR}$ (DMSO- $d_{6}$, $600 \mathrm{MHz}) \delta: 8.29(2 \mathrm{H}, \mathrm{d}, J=9.0 \mathrm{~Hz}), 7.75(2 \mathrm{H}, \mathrm{d}, J=9.0 \mathrm{~Hz})$, $5.52(1 \mathrm{H}, \mathrm{d}, J=14.4 \mathrm{~Hz}), 5.39(1 \mathrm{H}, \mathrm{d}, J=14.4 \mathrm{~Hz}), 2.80(1 \mathrm{H}$, ddd, $J=6.6,9.6,17.4 \mathrm{~Hz}), 2.71(1 \mathrm{H}, \mathrm{ddd}, J=6.6,9.6,13.8 \mathrm{~Hz})$, $2.55(1 \mathrm{H}, \mathrm{ddd}, J=6.0,10.2,17.4 \mathrm{~Hz}), 2.39-2.35(1 \mathrm{H}, \mathrm{m})$; ${ }^{13} \mathrm{C}-\mathrm{NMR}$ (DMSO- $\left.d_{6}, 150 \mathrm{MHz}\right) \delta: 175.3,147.6,147.3,126.3$, 123.7, 84.3, 81.4, 32.9, 27.2; HRMS (DART) $\mathrm{m} / \mathrm{z}$ Calcd for $\mathrm{C}_{11} \mathrm{H}_{11} \mathrm{~N}_{2} \mathrm{O}_{6}\left[(\mathrm{M}+\mathrm{H})^{+}\right]:$267.06171. Found 267.06153.

Nitrolactonization of $\mathbf{3 d}$ A mixture of $\mathbf{3 d}(41.5 \mathrm{mg}$, $0.21 \mathrm{mmol})$ and $\mathrm{Fe}\left(\mathrm{NO}_{3}\right)_{3} \cdot 9 \mathrm{H}_{2} \mathrm{O}(41.6 \mathrm{mg}, 0.11 \mathrm{mmol})$ in 1,2 -di- 
chlorobenzene $(2.1 \mathrm{~mL})$ was lowered into pre-heated oil bath $\left(130^{\circ} \mathrm{C}\right)$. After being stirred for $4 \mathrm{~h}$ at same temperature, the mixture was cooled to r.t. and the reaction was quenched by addition of sat. aq. $\mathrm{NaHCO}_{3}$. The resulting mixture was filtered through a pad of Celite. The filtrate was extracted with $\mathrm{CH}_{2} \mathrm{Cl}_{2}$. The extracts were washed with brine, and dried over $\mathrm{Na}_{2} \mathrm{SO}_{4}$, filtered, and concentrated. The residue was purified through silica gel column chromatography (hexane/ $\mathrm{AcOEt}=6 / 4$ to $1 / 1)$ to give 5-(4'-cyanophenyl)-5-nitromethyloxolan-2-one (5d) $(13.3 \mathrm{mg}, 26 \%)$ as pale yellow solid; $\mathrm{mp}$ : $174.5-175.0^{\circ} \mathrm{C}$; IR (neat) $\mathrm{cm}^{-1}$ : 2231, 1788, 1631, 1612, 1556; ${ }^{1} \mathrm{H}-\mathrm{NMR}$ (methanol- $\left.d_{4}, 400 \mathrm{MHz}\right) \delta: 7.81(2 \mathrm{H}, \mathrm{d}, J=8.8 \mathrm{~Hz}$ ), $7.66(2 \mathrm{H}, \mathrm{d}, J=8.8 \mathrm{~Hz}), 5.20(1 \mathrm{H}, \mathrm{d}, J=13.6 \mathrm{~Hz}), 5.14(1 \mathrm{H}, \mathrm{d}$, $J=13.6 \mathrm{~Hz}), 2.88-2.70(2 \mathrm{H}, \mathrm{m}), 2.61-2.51(2 \mathrm{H}, \mathrm{m}) ;{ }^{13} \mathrm{C}-\mathrm{NMR}$ (DMSO- $\left.d_{6}, 150 \mathrm{MHz}\right) \delta$ : 175.4, 145.6, 132.6, 125.8, 118.4, 111.1, 84.3, 81.3, 32.8, 27.1; HRMS (DART) $\mathrm{m} / \mathrm{z}$ Calcd for $\mathrm{C}_{12} \mathrm{H}_{14} \mathrm{~N}_{3} \mathrm{O}_{4}\left[\left(\mathrm{M}+\mathrm{NH}_{4}\right)^{+}\right]: 264.09843$. Found 264.09788.

Nitrolactonization of $8 \mathrm{a}$ A mixture of $8 \mathbf{a}(56.0 \mathrm{mg}$, $0.25 \mathrm{mmol})$ and $\mathrm{Fe}\left(\mathrm{NO}_{3}\right)_{3} \cdot 9 \mathrm{H}_{2} \mathrm{O} \quad(50.5 \mathrm{mg}, 0.13 \mathrm{mmol})$ in 1,2-dichlorobenzene $(2.5 \mathrm{~mL})$ was lowered into pre-heated oil bath $\left(130^{\circ} \mathrm{C}\right)$. After being stirred for $22 \mathrm{~h}$ at same temperature, the mixture was cooled to r.t. and the reaction was quenched by addition of sat. aq. $\mathrm{NaHCO}_{3}$. The resulting mixture was filtered through a pad of Celite. The filtrate was extracted with $\mathrm{CH}_{2} \mathrm{Cl}_{2}$. The extracts were washed with brine, and dried over $\mathrm{Na}_{2} \mathrm{SO}_{4}$, filtered, and concentrated. The residue was purified through silica gel column chromatography (hexane/AcOEt $=9 / 1$ to $3 / 1$ ) to give 3 -(nitromethyl)3-phenylisobenzofuran-1(3H)-one $(\mathbf{9 a})^{44)}(62.8 \mathrm{mg}, 93 \%)$ as a white solid; $\mathrm{mp}: 128.5-130.0^{\circ} \mathrm{C}$; IR $\left(\mathrm{CHCl}_{3}\right) \mathrm{cm}^{-1}$ : 1782, 1562; ${ }^{1} \mathrm{H}-\mathrm{NMR}\left(\mathrm{CDCl}_{3}, 400 \mathrm{MHz}\right) \delta: 7.96-7.40(9 \mathrm{H}, \mathrm{m}), 5.26(1 \mathrm{H}$, $\mathrm{d}, J=12.8 \mathrm{~Hz}), 5.17(1 \mathrm{H}, \mathrm{d}, J=12.8 \mathrm{~Hz}) ;{ }^{13} \mathrm{C}-\mathrm{NMR}\left(\mathrm{CDCl}_{3}\right.$, $150 \mathrm{MHz}) \delta$ : 168.1, 147.5, 136.0, 134.7, 130.5, 129.6, 129.3, $126.5,125.7,125.1,122.9,85.5,80.2$; HRMS (DART) $\mathrm{m} / \mathrm{z}$ Calcd for $\mathrm{C}_{15} \mathrm{H}_{12} \mathrm{NO}_{4}\left[(\mathrm{M}+\mathrm{H})^{+}\right]: 270.07663$. Found 270.07407.

Nitrolactonization of $\mathbf{8 b}$ A mixture of $\mathbf{8 b}(35.6 \mathrm{mg}$, $0.14 \mathrm{mmol})$ and $\mathrm{Fe}\left(\mathrm{NO}_{3}\right)_{3} \cdot 9 \mathrm{H}_{2} \mathrm{O}(28.3 \mathrm{mg}, 0.07 \mathrm{mmol})$ in 1,2 -dichlorobenzene $(1.4 \mathrm{~mL})$ was lowered into pre-heated oil bath $\left(130^{\circ} \mathrm{C}\right)$. After being stirred for $30 \mathrm{~min}$ at same temperature, the mixture was cooled to r.t. and the reaction was quenched by addition of sat. aq. $\mathrm{NaHCO}_{3}$. The resulting mixture was filtered through a pad of Celite. The filtrate was extracted with $\mathrm{CH}_{2} \mathrm{Cl}_{2}$. The extracts were washed with brine, and dried over $\mathrm{Na}_{2} \mathrm{SO}_{4}$, filtered, and concentrated. The residue was purified through silica gel column chromatography (hexane/ AcOEt $=9 / 1$ to $7 / 3$ ) to give 3-nitromethyl-3-(4'-methoxypheyl)isobenzofuran-1(3H)-one (9b) $(26.9 \mathrm{mg}, 65 \%)$ and 3-methyl-3(4'-methoxyphenyl)isobenzofuran-1(3H)-one (10b) (10.5 mg, $30 \%)$, respectively.

3-Nitromethyl-3-(4'-methoxy phenyl)isobenzofuran-1(3H)one $(9 b)$

White solid; mp: $49.0-50.0^{\circ} \mathrm{C}$; IR $\left(\mathrm{CHCl}_{3}\right) \mathrm{cm}^{-1}$ : 1780, 1560; ${ }^{1} \mathrm{H}-\mathrm{NMR}\left(\mathrm{CDCl}_{3}, 400 \mathrm{MH}\right) \delta: 7.96-7.60(4 \mathrm{H}, \mathrm{m}), 7.45(2 \mathrm{H}, \mathrm{d}$, $J=9.2 \mathrm{~Hz}), 6.92(2 \mathrm{H}, \mathrm{d}, J=9.2 \mathrm{~Hz}), 5.23(1 \mathrm{H}, \mathrm{d}, J=13.0 \mathrm{~Hz})$, $5.14(1 \mathrm{H}, \mathrm{d}, J=13.0 \mathrm{~Hz}), 3.80(3 \mathrm{H}, \mathrm{s}) ;{ }^{13} \mathrm{C}-\mathrm{NMR}\left(\mathrm{CDCl}_{3}\right.$, $150 \mathrm{MHz}) \delta: 168.2,160.3,147.6,134.6,130.9,127.7,126.7$, 126.3, 125.7, 123.0, 114.5, 85.5, 80.2, 55.3; HRMS (DART) $\mathrm{m} / \mathrm{z}$ Calcd for $\mathrm{C}_{16} \mathrm{H}_{14} \mathrm{NO}_{5}\left[(\mathrm{M}+\mathrm{H})^{+}\right]$: 300.08720 . Found 300.08665 .

3-Methyl-3-(4'-methoxyphenyl)isobenzofuran-1(3H)-one $(\mathbf{1 0 b})^{49)}$

Pale yellow oil; IR $\left(\mathrm{CHCl}_{3}\right) \quad \mathrm{cm}^{-1}: 1759,1514,1255$;
${ }^{1} \mathrm{H}-\mathrm{NMR} \quad\left(\mathrm{CDCl}_{3}, 400 \mathrm{MHz}\right) \quad \delta: 7.91 \quad(1 \mathrm{H}, \mathrm{d}, J=8.0 \mathrm{~Hz})$, $7.66(1 \mathrm{H}, \mathrm{t}, J=7.6 \mathrm{~Hz}), 7.52(1 \mathrm{H}, \mathrm{t}, J=7.6 \mathrm{~Hz}), 7.42(1 \mathrm{H}, \mathrm{d}$, $J=8.0 \mathrm{~Hz}), 7.33(2 \mathrm{H}, \mathrm{d}, J=9.0 \mathrm{~Hz}), 6.86(2 \mathrm{H}, \mathrm{d}, J=9.0 \mathrm{~Hz})$, $3.79(3 \mathrm{H}, \mathrm{s}), 2.03(3 \mathrm{H}, \mathrm{s}) ;{ }^{13} \mathrm{C}-\mathrm{NMR}\left(\mathrm{CDCl}_{3}, 150 \mathrm{MHz}\right) \delta$ : $170.0,159.5,154.4,134.2,132.5,129.0,126.6,125.8,125.2$, 122.0, 113.9, 87.6, 55.3, 27.1; HRMS (DART) $\mathrm{m} / \mathrm{z}$ Calcd for $\mathrm{C}_{16} \mathrm{H}_{15} \mathrm{O}_{3}\left[(\mathrm{M}+\mathrm{H})^{+}\right]:$255.10212. Found 255.10299. The spectral data were identified with the reported ones.

Nitrolactonization of $\mathbf{8 c}$ A mixture of $8 \mathbf{c}(59.6 \mathrm{mg}$, $0.25 \mathrm{mmol})$ and $\mathrm{Fe}\left(\mathrm{NO}_{3}\right)_{3} \cdot 9 \mathrm{H}_{2} \mathrm{O}(50.5 \mathrm{mg}, 0.13 \mathrm{mmol})$ in 1,2-dichlorobenzene $(2.5 \mathrm{~mL})$ was lowered into pre-heated oil bath $\left(130^{\circ} \mathrm{C}\right)$. After being stirred for $30 \mathrm{~min}$ at same temperature, the mixture was cooled to r.t. and the reaction was quenched by addition of sat. aq. $\mathrm{NaHCO}_{3}$. The mixture was filtered through a pad of Celite and the filtrate was extracted with $\mathrm{CH}_{2} \mathrm{Cl}_{2}$. The extracts were washed with brine, and dried over $\mathrm{Na}_{2} \mathrm{SO}_{4}$, filtered, and concentrated. The residue was purified through silica gel column chromatography (hexane/AcOEt $=9 / 1$ to $7 / 3$ ) to give 3-nitromethyl-3-( $p$-tolyl)isobenzofuran-1(3H)-one (9c) $(63.0 \mathrm{mg}, 89 \%)$ and 3-methyl-3( $p$-tolyl)isobenzofuran-1(3H)-one (10c) $(7.0 \mathrm{mg}, 11 \%)$, respectively.

3-Nitromethyl-3-( $p$-tolyl)isobenzofuran-1(3H)-one (9c)

White solid; mp: $99.0-100.5^{\circ} \mathrm{C}$; IR $\left(\mathrm{CHCl}_{3}\right) \mathrm{cm}^{-1}$ : 1780 , $1560 ;{ }^{1} \mathrm{H}-\mathrm{NMR}\left(\mathrm{CDCl}_{3}, 400 \mathrm{MHz}\right) \delta: 7.94(1 \mathrm{H}, \mathrm{d}, J=7.6 \mathrm{~Hz})$, $7.78-7.74(1 \mathrm{H}, \mathrm{m}), 7.72(1 \mathrm{H}, \mathrm{d}, J=7.6 \mathrm{~Hz}), 7.63-7.59(1 \mathrm{H}, \mathrm{m})$, $7.43(2 \mathrm{H}, \mathrm{d}, J=8.2 \mathrm{~Hz}), 7.23(2 \mathrm{H}, \mathrm{d}, J=8.2 \mathrm{~Hz}), 5.24(1 \mathrm{H}, \mathrm{d}$, $J=13.0 \mathrm{~Hz}), 5.16(1 \mathrm{H}, \mathrm{d}, J=13.0 \mathrm{~Hz}), 2.35(3 \mathrm{H}, \mathrm{s}) ;{ }^{13} \mathrm{C}-\mathrm{NMR}$ $\left(\mathrm{CDCl}_{3}, 150 \mathrm{MHz}\right) \delta: 168.2,147.7,139.6,134.6,133.0,130.3$, $129.9,126.3,125.6,124.9,122.9,85.5,80.1,21.0$; HRMS (DART) $m / z$ Calcd for $\mathrm{C}_{16} \mathrm{H}_{14} \mathrm{NO}_{4}\left[(\mathrm{M}+\mathrm{H})^{+}\right]$: 284.09228 . Found 284.09152.

3-Methyl-3-( $p$-tolyl)isobenzofuran-1(3H)-one (10c)

Pale yellow oil; IR $\left(\mathrm{CHCl}_{3}\right) \mathrm{cm}^{-1}$ : 1759, 1514; ${ }^{1} \mathrm{H}-\mathrm{NMR}$ $\left(\mathrm{CDCl}_{3}, 400 \mathrm{MHz}\right) \delta: 7.90(1 \mathrm{H}, \mathrm{d}, J=7.6 \mathrm{~Hz}), 7.67-7.63(1 \mathrm{H}$, m), 7.53-7.49 (1H, m), $7.44(1 \mathrm{H}, \mathrm{d}, J=7.6 \mathrm{~Hz}), 7.32(2 \mathrm{H}, \mathrm{d}$, $J=7.8 \mathrm{~Hz}), 7.16(2 \mathrm{H}, \mathrm{d}, J=7.8 \mathrm{~Hz}), 2.33(3 \mathrm{H}, \mathrm{s}), 2.03(3 \mathrm{H}$, $\mathrm{s}) ;{ }^{13} \mathrm{C}-\mathrm{NMR}\left(\mathrm{CDCl}_{3}, 150 \mathrm{MHz}\right) \delta: 170.0,154.4,138.2,137.7$, $134.2,129.3,129.0,125.8,125.08,125.06,122.0$, 87.6, 27.2, 21.0; HRMS (DART) $m / z$ Calcd for $\mathrm{C}_{16} \mathrm{H}_{15} \mathrm{O}_{2}\left[(\mathrm{M}+\mathrm{H})^{+}\right]$: 239.10720. Found 239.10637.

Nitrolactonization of $\mathbf{8 d}$ A mixture of $\mathbf{8 d ~}(33.2 \mathrm{mg}$, $0.11 \mathrm{mmol})$ and $\mathrm{Fe}\left(\mathrm{NO}_{3}\right)_{3} \cdot 9 \mathrm{H}_{2} \mathrm{O}(22.1 \mathrm{mg}, 0.06 \mathrm{mmol})$ in 1,2-dichlorobenzene $(1.1 \mathrm{~mL})$ was lowered into pre-heated oil bath $\left(130^{\circ} \mathrm{C}\right)$. After being stirred for $30 \mathrm{~min}$ at same temperature, the mixture was cooled into r.t. and the reaction was quenched by addition of sat. aq. $\mathrm{NaHCO}_{3}$. The resulting mixture was filtered through a pad of Celite and the filtrate was extracted with $\mathrm{CH}_{2} \mathrm{Cl}_{2}$. The extracts were washed with brine, and dried over $\mathrm{Na}_{2} \mathrm{SO}_{4}$, filtered, and concentrated. The residual oil was purified through silica gel column chromatography (hexane/AcOEt $=9 / 1$ to $7 / 3$ ) to give 3-(4'-bromophenyl)3-nitromethylisobenzofuran-1(3H)-one (9d) as white solid; mp: $104.0-104.5^{\circ} \mathrm{C}$; IR $\left(\mathrm{CHCl}_{3}\right) \mathrm{cm}^{-1}: 1784,1558 ;{ }^{1} \mathrm{H}-\mathrm{NMR}$ $\left(\mathrm{CDCl}_{3}, 400 \mathrm{MHz}\right) \delta: 7.96(1 \mathrm{H}, \mathrm{d}, J=7.6 \mathrm{~Hz}), 7.80-7.76(1 \mathrm{H}$, m), $7.70(1 \mathrm{H}, \mathrm{d}, J=7.6 \mathrm{~Hz}), 7.66-7.62(1 \mathrm{H}, \mathrm{m}), 7.57(2 \mathrm{H}, \mathrm{d}$, $J=8.6 \mathrm{~Hz}), 7.45(2 \mathrm{H}, \mathrm{d}, J=8.6 \mathrm{~Hz}), 5.22(1 \mathrm{H}, \mathrm{d}, J=13.2 \mathrm{~Hz})$, $5.12(1 \mathrm{H}, \mathrm{d}, J=13.2 \mathrm{~Hz}) ;{ }^{13} \mathrm{C}-\mathrm{NMR}\left(\mathrm{CDCl}_{3}, 150 \mathrm{MHz}\right) \delta: 167.8$, $147.1,135.1,134.9,132.5,130.7,126.8,126.7,125.5,124.0$, 122.7, 84.9, 80.0; HRMS (DART) $\mathrm{m} / z$ Calcd for $\mathrm{C}_{15} \mathrm{H}_{14} \mathrm{BrN}_{2} \mathrm{O}_{4}$ $\left[\left(\mathrm{M}+\mathrm{NH}_{4}\right)^{+}\right]:$365.01369. Found 365.01524. 
Experiment for Chart 4 Di-tert-butylhydroxytoluene (BHT) $(132.2 \mathrm{mg}, 0.6 \mathrm{mmol})$ was added to a mixture of $\mathbf{8 a}$ $(44.9 \mathrm{mg}, 0.2 \mathrm{mmol})$ and $\mathrm{Fe}\left(\mathrm{NO}_{3}\right)_{3} \cdot 9 \mathrm{H}_{2} \mathrm{O}(40.4 \mathrm{mg}, 0.1 \mathrm{mmol})$ in 1,2-dichlorobenzene $(2.0 \mathrm{~mL})$. The mixture was lowered into pre-heated oil bath $\left(130^{\circ} \mathrm{C}\right)$. After being stirred for $19 \mathrm{~h}$ at same temperature, the mixture was cooled to r.t. and the reaction was quenched by addition of sat. aq. $\mathrm{NaHCO}_{3}$. The resulting mixture was filtered through a pad of Celite. The filtrate was acidified the $4 \mathrm{~N} \mathrm{HCl}$ and extracted with $\mathrm{CH}_{2} \mathrm{Cl}_{2}$. The extracts were washed with water, brine, and dried over $\mathrm{Na}_{2} \mathrm{SO}_{4}$, filtered, and concentrated. The residue was chromatographed on silica gel (hexane/AcOEt $=9 / 1$ to $8 / 2$ ) to give a mixture of 9a $(12 \%)$ and $\mathbf{8 a}(16 \%)$, respectively. The yields of $9 \mathbf{a}$ and $\mathbf{8 a}$ were determined by qNMR using 1,4-dinitrobenzene as an internal standard.

Acknowledgments This research was supported by JSPS KAKENHI Grant Number JP17K08208.

Conflict of Interest The authors declare no conflict of interest.

Supplementary Materials The online version of this article contains supplementary materials.

\section{References and Notes}

1) Ballini R., Palmieri A., Adv. Synth. Catal., 361, 5070-5097 (2019).

2) Evans C. S., Davis L. O., Molecules, 23, 33-45 (2018).

3) Dong L., Chen F.-E., RCS Adv., 10, 2313-2326 (2020).

4) Zhang S., Li Y., Xu Y., Wang Z., Chin. Chem. Lett., 29, 873-883 (2018).

5) Saranya S., Harry N. A., Ujwaldev S. M., Anikumar G., Asian J. Org. Chem., 6, 1349-1360 (2017)

6) Wonner P., Dreger A., Vogel L., Engelage E., Huber S. M., Angew. Chem. Int. Ed., 58, 16923-16927 (2019).

7) Aguesseau-Kondrotas J., Simon M., Legrand B., Bantigniès J.-J., Kang Y. K., Dumitrescu D., Van der Lee A., Campagne J.-M., de Figueiredo R. M., Maillard L. T., Chem. Eur. J., 25, 7396-7401 (2019).

8) Wang Y., Lin J.-B., Xie J.-K., Lu H., Hu X.-Q., Xu P.-F., Org. Lett., 20, 5835-5839 (2018).

9) Kawamoto Y., Ozone D., Kobayashi T., Ito H., Org. Biomol. Chem., 16, 8477-8480 (2018).

10) Peng F., Chen Y., Chen C.-y., Dormer P. G., Kassim A., McLaughlin M., Reamer R. A., Sherer E. C., Song Z. J., Tan L., Tudge M. T., Wan B., Chung J. Y. L., J. Org. Chem., 82, 9023-9029 (2017).

11) Uraguchi D., Nakamura S., Sasaki H., Konakade Y., Ooi T., Chem. Commun., 50, 3491-3493 (2014).

12) Shimkin K. W., Gildner P. G., Watson D. A., Org. Lett., 18, $988-$ 991 (2016).

13) Gietter A. A. S., Gildner P. G., Cinderella A. P., Watson D. A., Org. Lett., 16, 3166-3169 (2014).

14) Zhu J. S., Haddadin M. J., Kurth M. J., Acc. Chem. Res., 52, $2256-$ $2265(2019)$

15) Vasilenko D. A., Sedenkova K. N., Kuznetsova T. S., Averina E. B., Synthesis, 51, 1516-1528 (2019).

16) Tabolin A. A., Sukhorukov A. Y., Ioffe S. L., Dilman A. D., Synthesis, 49, 3255-3268 (2017).

17) Ballini R., Petrini M., Adv. Synth. Catal., 357, 2371-2402 (2015).

18) Ballini R., Petrini M., Tetrahedron, 60, 1017-1047 (2004).
19) Orlandi M., Brenna D., Harms R., Jost S., Benaglia M., Org. Process Res. Dev., 22, 430-445 (2018).

20) Khan F., Dlugosch M., Liu X., Banwell M. G., Acc. Chem. Res., 51 1784-1795 (2018).

21) Aksenov N. A., Aksenov A. V., Kornienko A., De Carvalho A., Mathieu V., Aksenov D. A., Ovcharov S. N., Griaznov G. D., Rubin M., RSC Adv., 8, 36980-36986 (2018).

22) Sim J. H., Song C. E., Angew. Chem. Int. Ed., 56, 1835-1839 (2017).

23) Wang Y., Lu H., Xu P.-F., Acc. Chem. Res., 48, 1832-1844 (2015).

24) Liu L.-Q., Chen J.-R., Xiao W.-J., Acc. Chem. Res., 45, 1278-1293 (2012).

25) Adams J. P., J. Chem. Soc., Perkin Trans. 1, 2586-2597 (2002).

26) Taniguchi T., Ishibashi H., Org. Lett., 12, 124-126 (2010).

27) Taniguchi T., Fujii T., Ishibashi H., J. Org. Chem., 75, 8126-8132 (2010).

28) Sabbasani V. R., Lee D., Org. Lett., 15, 3954-3957 (2013).

29) Motornov V. A., Muzalevskiy V. M., Taboli A. A., Novikov R. A., Nelyubina Y. V., Nenajdenko V. G., Ioffe S. L., J. Org. Chem., 82, 5274-5284 (2017).

30) Naveen T., Maity S., Sharma U., Maiti D., J. Org. Chem., 28, 59495954 (2013)

31) Sar D., Bag R., Bhattacharjee D., Deka R. C., Punniyamurthy T., J. Org. Chem., 80, 6776-6783 (2015).

32) Yang T., Zhou J.-L., Li J., Shen Y., Gao C., Li Y.-M., Synthesis, 50, 3460-3466 (2018).

33) Yang Z., Li J., Hua J., Yang T., Yi J., Zhou C., Synlett, 28, 1079$1082(2017)$

34) Yi X., Chen K., Chen W., Chen W., Liu M., Wu H., Org. Biomol. Chem., 17, 4725-4728 (2019).

35) Chen D., Ji M., Zhu C., Chem. Commun., 55, 7796-7799 (2019).

36) For generation of nitrogen dioxide from $\mathrm{Fe}\left(\mathrm{NO}_{3}\right)_{3} \cdot 9 \mathrm{H}_{2} \mathrm{O}$ was cited in ref 26.

37) Amaya T., Fujimoto H., Tetrahedron Lett., 59, 2657-2660 (2018).

38) Crystal data of 5a: $\mathrm{C}_{11} \mathrm{H}_{11} \mathrm{NO}_{4}, M=221.21$, space group $P 2_{1} / \mathrm{c}(\# 14)$, $a=14.342(3) \AA, b=5.7784(10) \AA, c=13.439(3) \AA, \alpha=90^{\circ}, \beta=107.737(8)^{\circ}$, $\gamma=90^{\circ}, \quad V=1060.9(4) \AA^{3}, \mathrm{Z}=4, \rho_{\text {Calcd }}=1.385 \mathrm{~g} / \mathrm{cm}^{3}, \quad M o K_{\alpha}$ radiation, $\lambda=0.71075 \AA, \mu=0.107 \mathrm{~mm}^{-1}, T=296 \mathrm{~K}$. The final $R 1$ and $\mathrm{w} R 2$ were 0.0617 and 0.1641 for 145 parameters. CCDC 1987404 contains the supplementary crystallographic data for this paper. These data can be obtained free of charge from The Cambridge Crystallographic Data Centre via www.ccdc.cam.ac.uk/data_request/cif.

39) Zakharov I. I., Theor. Exp. Chem., 48, 233-239 (2012).

40) Shiri M., Zolfigol M. A., Kruger H. G., Tanbakouchian Z., Tetrahedron, 66, 9077-9106 (2010).

41) Addison C. C., Chem. Rev., 80, 21-39 (1980).

42) Ogata Y., Tabushi I., J. Synth. Org. Chem. Jpn., 15, 341-360 (1957).

43) Riebsomer J. L., Chem. Rev., 36, 157-233 (1945).

44) Xiong Y.-S., Zhang B., Yu Y., Weng J., Lu G., J. Org. Chem., 84, 13465-13472 (2019).

45) Levy N., Scaife C. W., Wilder-Smith A. E., J. Chem. Soc., 52-60 (1948).

46) Sha W., Zhang W., Ni S., Mei H., Han J., Pan Y., J. Org. Chem., 82, 9824-9831 (2017).

47) Zhou L., Tan C. K., Jiang X., Chen F., Yeung Y.-Y., J. Am. Chem. Soc., 132, 15474-15476 (2010).

48) Zhu R., Buchwald S. L., J. Am. Chem. Soc., 137, 8069-8077 (2015).

49) Guo L.-N., Gu Y.-R., Yang H., Hu J., Org. Biomol. Chem., 14, 3098-3104 (2016).

50) Jõgi A., Paju A., Pehk T., Kailas T., Müürisepp A.-M., Lopp M., Tetrahedron, 65, 2959-2967 (2009).

51) Yus M., Torregrosa R., Pastor I. M., Molecules, 9, 330-348 (2004).

52) Wang B., Shen Y.-M., Shi Y., J. Org. Chem., 71, 9519-9521 (2006). 